\title{
BLOOD LACTATE AND LACTATE PYRUVATE RATIO AS PROGNOSTIC BIOMARKERS OF OUTCOME IN ACUTE ALUMINUM PHOSPHIDE POISONING
}

\author{
Aliaa Abd Elhakam Hodeib ${ }^{a}$, Naema Mahmoud Elhosary ${ }^{a^{*}}$ \\ ${ }^{a}$ Forensic Medicine and Clinical Toxicology Department, Faculty of Medicine, Tanta University, \\ Tanta, Egypt \\ * Corresponding author: Naema Mahmoud Elhosary. Assistant Professor of Forensic Medicine and \\ Clinical Toxicology, Forensic Medicine and Clinical Toxicology Department, Faculty of Medicine, \\ Tanta University, Tanta, Egypt. Email: drnaemam2020@gmail.com,Tel:00966555869863
}

\begin{abstract}
Aluminium phosphide (AIP) is a toxic pesticide accompanied by a high mortality rate after acute exposure from different routes. Objectives: evaluation of blood level of lactate, pyruvate and lactate/pyruvate (L/P) ratio as outcome predictors of AlP poisoning. Methodology: All patients with a confirmed diagnosis of acute AlP poisoning who admitted to Poison Control Center- Emergency Hospital-Tanta University, Tanta, Egypt, from October 2019 to end of November 2019 were included. All studied patients (46) underwent thorough history taking, physical examination and routine laboratory investigations. Three $\mathrm{mL}$ of blood were used for determination of lactate and pyruvate levels. Results: The predominant manner of poisoning was suicidal due to ingestion of AlP tablets. The mortality rate was $73.9 \%$. Systolic blood pressure (SBP) and diastolic blood pressure (DBP) were recorded with statistical significant difference between both studied groups. Oxygen saturation, $\mathrm{pH}, \mathrm{HCO}_{3}, \mathrm{PO}_{2}$, mean blood hemoglobin, potassium (K) and magnesium $(\mathrm{Mg})$ were statistically reduced in non- survival group compared with survival group. Lactate and L/P ratio showed significant rise in non-survived patients, while pyruvate presented statistically non-significant difference between the studied groups. The blood $\mathrm{pH}$ had the highest discriminatory power as regards mortality, followed by DBP on admission, then SBP on admission, lactate, L/P ratio, respiratory rate and pyruvate. The blood lactate and L/P ratio had $100 \%$ sensitivity and $66.7 \%$ specificity. Conclusion: Blood lactate level was indicated as an outcome biomarker of acute AlP poisoning. KEYWORDS: Aluminum phosphide poisoning, Lactate, Pyruvate, Lactate/Pyruvate ratio, Outcome

\section{INTRODUCTION}

Aluminum Phosphide (AlP) is highly powerful pesticides. It is used as a fumigant for stored grains protection and during their transportation. AlP is toxic to all stages of insects, don't alter the seeds viability and leaves no toxic residues in the environment except for

little amount on food cultivated crops. (Proudfoot, 2009 and Moghadamnia, 2012).

In Egypt, AlP is known as WHEAT PILL and/or RICE PILL in other parts of the world. The common trade names include Celphos, Alphos, Quickphos, Phostek, Delicia and Chemfume (Gurjar, M., et al. 2011). Acute AlP poisoning occurs either suicidal by direct
\end{abstract}


ingestion especially in young adult or accidental due to inhalation of phosphine gas during occupational exposure (Chaudhary et al., 2013). Phosphides self-poisoning is evolved as a greatly public health problem which is documented by high reported rate of morbidity and mortality which ranges from $37 \%$ to $100 \%$ (Bumbrah et al., 2012). This may be attributable to its cheapness and easy accessibility (Sagah et al., 2015 and Hegazy et al., 2019). According to El-Sarnagawy (2017) death occurred in $44.7 \%$ of acutely AlP poisoned patients who were admitted to Tanta Poison Control Centre during the period from 2012 to 2016.

Acute aluminum phosphide toxicity follows its contact with air moisture or gastric juice liberating phosphine gas which is absorbed throughout the mucosal lining of gastrointestinal tract and lungs, where it blocks mitochondrial cytochrome $\mathrm{C}$ oxidase, inhibiting oxidative phosphorylation and histotoxic hypoxia is induced (Mehrpour et al., 2012, Sweilum et al., 2017).

Clinical manifestations of toxicity appear shortly after exposure in the form of nausea, vomiting, restlessness, abdominal pain, palpitation, intractable shock, arrhythmias, pulmonary edema, dyspnea, cyanosis and sensory variations (Mehrpour et al., 2012). Additionally, Proudfoot (2009) reported that $40 \%-91 \%$ of deaths occur within the first $24 \mathrm{~h}$ of exposure due to cardiogenic shock and intractable hypotension, tachycardia, and electrocardiography troubles, many patients die despite intensive care, as there is no antidotal therapy (Ahmadi et al., 2018).

Pyruvate is an organic acid, which is generated as an end product of glycolysis. Under aerobic conditions, pyruvate is additionally oxidized to acetyl coenzyme, although under anaerobic conditions it produced lactate in a process called anaerobic glycolysis. Therefore, lactate is considered a marker of hypoxia (Kucherenko et al., 2018). Hyperlactatemia also originates from an increased lactate production or dropped its clearance (Mizock and Falk, 1992). Broder and Weil (1964) recommended the use of lactate as a clinical prognostic biomarker when they noticed hyperlactatemia and poor outcomes in undistinguishable shock. So, it considered a sign of systemic hypoperfusion leading to anaerobic metabolism (Andersen et al., 2013 \& Pundir et al., 2016).

Recently, blood lactate is used as a prognostic factor in poisoned patients with metformin, acetaminophen, beta blockers, carbon monoxide, cyanide and paraquat. (Mégarbane et al., 2010; Shah et al., 2011; Cervellin et al., 2014; Erfantalab et al., 2017; Yeh et al., 2017). The aim of this study was to evaluate blood lactate and pyruvate concentrations as predictors of outcome in AlP poisoning.

\section{PATIENTS AND METHODS}

\section{Study Design and Ethical Consideration:}

This study was hospital based prospective study. Patients with acute AlP poisoning admitted to Poison Control Center- Emergency Hospital-Tanta University, Tanta, Egypt, from beginning of October 2019 to end of November 2019 were enrolled. This study was approved by the Ethical Committee of Faculty of Medicine, Tanta University, Egypt (Approval Code: 33339/09/19). All included patients or their relatives signed an informed written consent regarding the analysis of their medical data after declaring the objectives and research plan. All patients' information was securely coded and analyzed.

\section{PATIENTS:}

The diagnosis of acute phosphides poisoning was based on the history of exposure to AlP poison (either obtained from the patient or the accompanying relative), clinical manifestations, foul or decaying fish like breath odor, cardiac arrhythmias and metabolic acidosis. According to Poison Severity Score, only moderately to severely poisoned patients 
were included in the study. On the other hand, patients with history of co-ingestion with other drugs, cardiac, hepatic, renal, diabetes mellitus diseases, and asymptomatic or mild cases are excluded from the study.

All studied patients underwent thorough history taking which included age, sex, marital status, residence, route, manner of exposure, and amount of phosphides, time delay of hospital arrival and history of any acute or chronic diseases. Clinical Physical examination comprising vital signs (heart rate, blood pressure, respiratory rate, and temperature), cardiac, chest, and abdomen examinations were performed and recorded at the time of admission. The level of consciousness was evaluated according to Glasgow Coma Scale.

The admitted patients were managed according to the approved management protocol of Tanta poison Control Center. Gastric lavage was performed with sodium-bicarbonate, saline and activated charcoal. Airway protection was given before gastric lavage in required patients. Supportive treatment included intravenous (IV) fluids, vasopressors and inotropic drugs, sodium- bicarbonate infusion, magnesium sulphate infusion and proton pump inhibitors. Close monitoring of hemodynamic parameters, urine output, arterial blood pressure and arterial blood gas was regularly done. The primary outcome was categorized as survivor and non-survivor.

\section{METHODS:}

Ten $\mathrm{mL}$ of venous blood was extracted by venipuncture or through an indwelling catheter under complete aseptic maneuver; if possible no tourniquet was used. The collected blood was used for doing the routine laboratory tests in addition to the following tests:

1- Lactate measurement: $2 \mathrm{~mL}$ of blood was collected in sodium fluoride/ potassium oxalate tubes, cooled on ice immediately and separated from the cells within 15 minutes. Once the plasma is separated from the cells, lactate values are stable. Lactate concentration is determined using an enzymatic colorimetric method by measuring the increase in absorbance at $536 \mathrm{~nm}$ (Kit was purchased from Egyptian Company for Biotechnology, Obour City, Cairo, Egypt).

2- $\quad$ For pyruvate determination, blood was drawn directly into syringe to add exactly $1 \mathrm{~mL}$ of it to the precooled special collection tube which contains $2.5 \mathrm{~mL}$ of perchloric acid 6\% (El-NASR, Pharmaceutical Chemicals Company, Cairo, Egypt) then shake vigorously to mix. Pyruvate level is quantified using an enzymatic colorimetric method by measuring the decrease of absorbance at $340 \mathrm{~nm}$ (Kit purchased from Biochemical Enterprise, Daignostic Solutions Company, Milano, Italy).

Both tests were performed in the Clinical Biochemistry Laboratory at Faculty of Medicine, Tanta University (using MYRA Chem Semi-Automated Biochemistry Analyzer, Meril Diagnostics Company, Gujarat, India).

\section{Statistical analysis}

Statistical analysis was performed using MedCalc Statistical Software version 15.8. For quantitative data, the Shapiro-Wilk test for normality was performed. For data that followed normal distribution, values were expressed as mean \pm standard deviation. Comparisons between the survivors and nonsurvivors were carried out using Independent Samples T-test. For data that did not follow normal distribution, median and interquartile range (IQR: expressed as $25^{\text {th }}-75^{\text {th }}$ percentiles) were calculated. Mann-Whitney test was used to compare between the two groups. Correlations between numerical variables were tested using Spearman's rank-order correlation.

For qualitative data, the variables were summarized as frequencies (count and percentage). Association between outcome and categorical variables were tested using Pearson's Chi square test for independence, Fisher's exact test, or Fisher-Freeman-Halton 
exact test as appropriate. The ROC curve was performed to analyze the relation between truepositive and false-positive results for each score. The AUC was graded as follows: 0.90-1 = excellent; $0.80-0.90$ = good; $0.70-0.80$ = fair; and $0.60-0.70=$ poor. Pairwise comparisons were made between the AUCs of the studied scores according to the method described by DeLong et al. (DeLong et al., 1988). Significance was adopted at $\mathrm{p}<0.05$ for interpretation of test results (Hinkle et al., 2003).

\section{RESULTS}

Table (1) showed that the studied patients were divided into two groups (Survivors and Non-survivors) based on their outcomes. The non-survived group accounts for $73.9 \%$ of the enrolled AlP poisoned patients in this study $(\mathrm{P}<$ $0.001)$. The range of age in survived patients was 17- 60 years and in non-survived patients was 16- 65 years with no statistically significance between both groups $(p=0.643)$. It was noticed that there was no statistically significant difference between two studied groups regarding sex and marital state $(p=0.397$ and 0.305 , respectively), while within the studied groups the female patients represented the majority of AlP poisoned patients $(58.3 \&$ $55.9 \%$, respectively). Patients came from AlBeheira governorate $(41.3 \%)$ were less than those who came from Al-Gharbia (58.69\%). The highest percent of survivors $(58.3 \%)$ was moderately educated while; most of nonsurvived patients were low educated $(47.1 \%)$. The majority of patients in both groups had not work (survivors; $83.3 \%$ \& non-survivors; 53\%). Regarding medical and psychiatric disorders, there was no statistically significant difference between survive and non-survived groups ( $\mathrm{p}=$ 0.560 and 0.317 ). Only $11.8 \%$ and $17.6 \%$ respectively among non-survived patients suffered from medical and psychiatric disorders.

The predominant manner of poisoning among both survivors and non survivors was suicidal $(\mathrm{P}<0.001)$ due to ingestion of AlP tablets with a range of $0.5-2.0$ in survivors and
$0.5-4.0$ in non survivors $(\mathrm{P}<0.003)$. Survived patients reached the hospital within $0.5-2.5$ hours, while non survivors arrived within $1.0-$ 6.0 hours $(\mathrm{P}<0.002)$ (Table 2$)$.

Table (3) revealed a statistical significant difference between both survival and nonsurvival groups regarding systolic and diastolic blood pressure, heart rate and respiratory rate at time of admission $(\mathrm{p}=0.001)$. Mean of oxygen

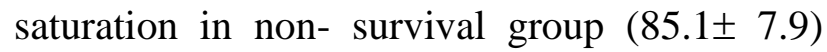
was statistically lower than survival group $(94.3 \pm 3.3)$ as $\mathrm{P}$ value was $<0.001$.

As displayed in Table (4), the mean blood hemoglobin was significantly lower in nonsurvived patients than survivors $(\mathrm{P}=0.024)$ and the mean INR of the non-survivors is significantly prolonged than survivors $(\mathrm{P}=$ 0.003). Additionally, there was significant decrease of $\mathrm{K}$ and $\mathrm{Mg}$ levels in the nonsurvivors compared with the survivors $(\mathrm{P}=$ $0.002,0.004)$, respectively.

Table (5 $\left.\begin{array}{lll}5 & 6\end{array}\right)$ disclosed a statistical significant difference between survived ad nonsurvived groups regarding $\mathrm{PH}, \mathrm{HCO} 3, \mathrm{PCO} 2$, Lactate and $\mathrm{L} / \mathrm{P}$ ratio $(\mathrm{p}=0.001)$. Mean of $\mathrm{PH}$ in survived group was 7.4 while in non- survived was 7.3. Mean of HCO3 in survived was 19.1 and in non -survived was 13.6. Range of PO2 was 79-96 in survived group and 37.8-99 in non -survived one. Statistical significance could be observed in hospital stay between two studied groups $(p=0.024)$ with longer duration in nonsurvived compared to survived group. Mean rank of lactate level in survived group was 12.5 and in non-survived it was 27.4, while the mean rank of lactate pyruvate ratio level in survived group was 12.8 and in non -survived it was 27.3.

As obvious in Table (7), significant positive correlations were recorded between the blood lactate level and the ingested amount of Al phosphides \& time delay to reach the hospital $(\mathrm{p}=0.001 \& 0.002$, respectively), while significant negative correlations between the blood lactate level and both $\mathrm{PH}$ and $\mathrm{Hco}_{3}$. Also a significant positive correlations were recorded 
between lactate pyruvate ratio and the ingested amount of $\mathrm{Al}$ phosphides \& time delay to reach the hospital $(\mathrm{p}=0.022 \& 0.001$, respectively), while significant negative correlations between lactate pyruvate ratio and both $\mathrm{PH}$ and $\mathrm{Hco}$.

Table (1): Statistical Distribution of sociodemographic data, medical and psychiatric history for survived and non-survived groups

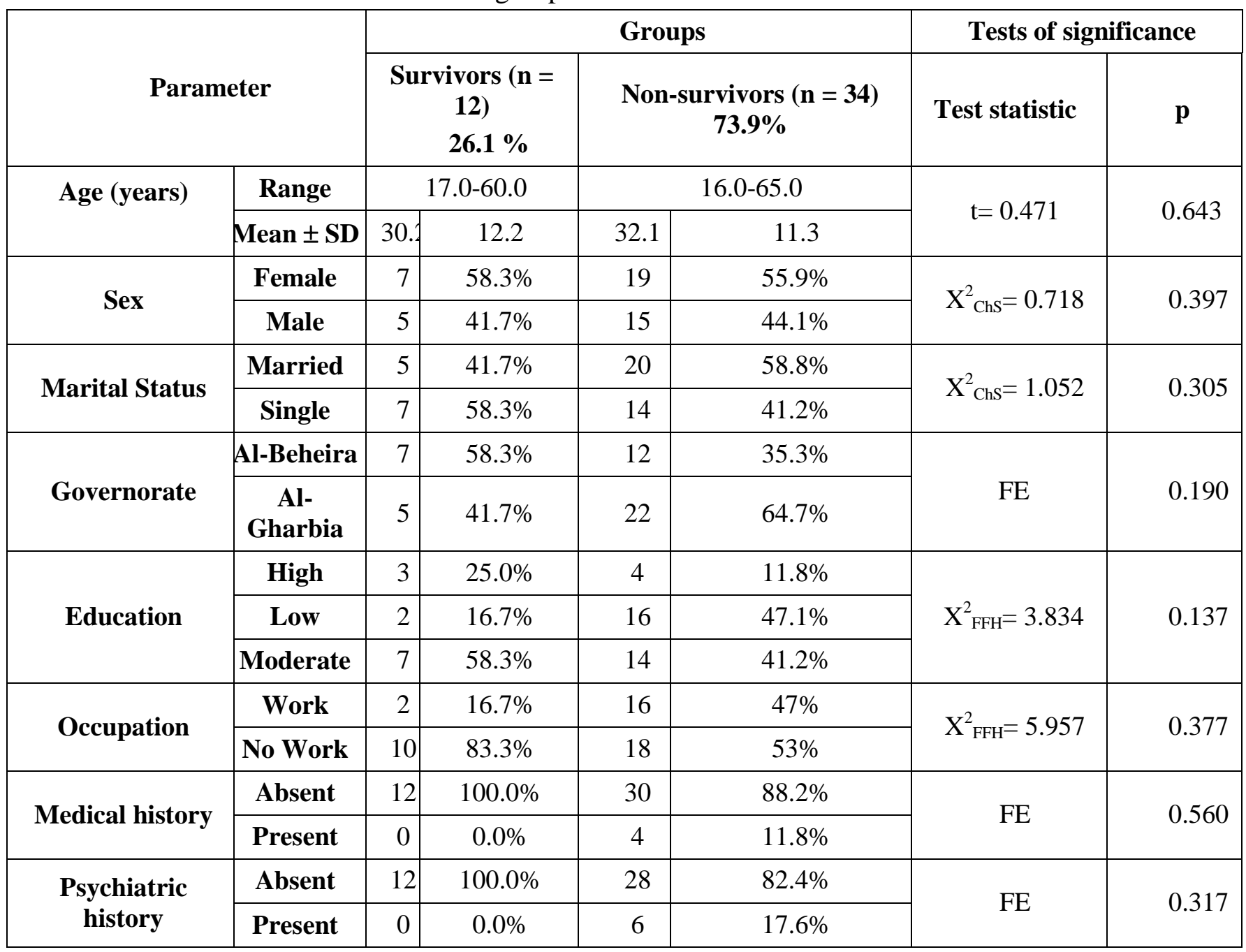

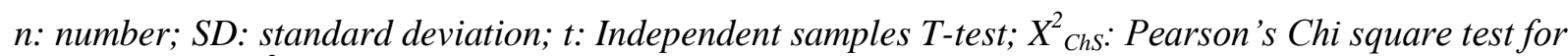
independence; $X_{F F H}^{2}$ : Fisher-Freeman-Halton exact test; FE: Fisher's exact test 
Table (2): Statistical comparison between the survivors and non-survivors regarding the manner of poisoning, amount of aluminum phosphide (ALP) ingested and time delay

\begin{tabular}{|c|c|c|c|c|c|c|c|}
\hline & \multicolumn{4}{|c|}{ Groups } & \multicolumn{2}{|c|}{ Tests of significance } \\
\hline & & \multicolumn{2}{|c|}{$\begin{array}{c}\text { Survivors } \\
(\mathrm{n}=12)\end{array}$} & \multicolumn{2}{|c|}{$\begin{array}{l}\text { Non-survivors } \\
\quad(\mathbf{n}=\mathbf{3 4})\end{array}$} & $\begin{array}{c}\text { Test } \\
\text { statistic }\end{array}$ & $\mathbf{p}$ \\
\hline \multirow[t]{2}{*}{ Manner of poisoning } & Accidental & 0 & $0.0 \%$ & 4 & $11.8 \%$ & \multirow[t]{2}{*}{$\mathrm{FE}$} & \multirow[t]{2}{*}{0.560} \\
\hline & Suicidal & 12 & $100.0 \%$ & 30 & $88.2 \%$ & & \\
\hline \multirow{3}{*}{$\begin{array}{l}\text { Amount of AlP (tablet } \\
=4 \mathrm{gm})\end{array}$} & Range & \multicolumn{2}{|c|}{$0.5-2.0$} & \multicolumn{2}{|c|}{$0.5-4.0$} & \multirow{3}{*}{$\begin{array}{l}\mathrm{Z}_{\mathrm{MW}}=- \\
2.165\end{array}$} & \multirow{3}{*}{$0.003 *$} \\
\hline & Median (IQR) & \multicolumn{2}{|c|}{21.4} & \multicolumn{2}{|c|}{24.2} & & \\
\hline & Mean rank & 1.0 & 0.8 to 2.0 & 1.0 & 1.0 to 2.0 & & \\
\hline \multirow{3}{*}{$\begin{array}{l}\text { Duration between } \\
\text { exposure and arrival to } \\
\text { hospital (hours) }\end{array}$} & Range & \multicolumn{2}{|c|}{$0.5-2.5$} & \multicolumn{2}{|c|}{$1.0-6.0$} & \multirow{3}{*}{$\begin{array}{l}\mathrm{Z}_{\mathrm{MW}}=- \\
3.123\end{array}$} & \multirow{3}{*}{$0.002 *$} \\
\hline & Median (IQR) & \multicolumn{2}{|c|}{21.0} & \multicolumn{2}{|c|}{24.4} & & \\
\hline & Mean rank & 2.3 & 1.3 to 2.5 & 2.0 & 1.3 to 5.0 & & \\
\hline
\end{tabular}

n: number; IQR: interquartile range; FE: Fisher's exact test; $Z_{M W}:$ Mann-Whitney test.

Table (3): Statistical comparison between survived $(n=12)$ and non-survived $(n=34)$ aluminum phosphide-poisoned patients regarding to GCS \& vital signs recorded on admission

\begin{tabular}{|c|c|c|c|c|c|}
\hline & & \multicolumn{2}{|c|}{ Groups } & \multicolumn{2}{|c|}{ Tests of significance } \\
\hline & & Survivors $(n=12)$ & $\begin{array}{c}\text { Non-survivors }(n= \\
\mathbf{3 4})\end{array}$ & $\begin{array}{c}\text { Test } \\
\text { statistic }\end{array}$ & $\mathbf{p}$ \\
\hline \multirow{3}{*}{ GCS } & Range & $13.0-15.0$ & $11.0-15.0$ & \multirow{3}{*}{$\begin{array}{l}\mathrm{Z}_{\mathrm{MW}}= \\
0.827\end{array}$} & \multirow{3}{*}{0.408} \\
\hline & $\begin{array}{l}\text { Median } \\
(\mathrm{IQR})\end{array}$ & $\begin{array}{r}15.0 \\
(13.0 \text { to } 15.0)\end{array}$ & $\begin{array}{c}14.5 \\
(13.0 \text { to } 15.0)\end{array}$ & & \\
\hline & Mean rank & 26.0 & 22.6 & & \\
\hline \multirow{2}{*}{$\begin{array}{l}\text { SBP on admission } \\
(\mathrm{mmHg})\end{array}$} & Range & $90.0-120.0$ & $70.0-120.0$ & \multirow{2}{*}{$t=5.688$} & \multirow{2}{*}{$<0.001^{*}$} \\
\hline & Mean $\pm S D$ & $113.3 \pm 11.5$ & $88.8 \pm 16.7$ & & \\
\hline \multirow{2}{*}{$\begin{array}{l}\text { DBP on admission } \\
(\mathrm{mmHg})\end{array}$} & Range & $70.0-80.0$ & $40.0-80.0$ & \multirow{2}{*}{$\mathrm{t}=7.379$} & \multirow{2}{*}{$<0.001 *$} \\
\hline & Mean \pm SD & $76.7 \pm 4.9$ & $55.3 \pm 14.7$ & & \\
\hline \multirow{2}{*}{$\begin{array}{l}\text { HR on admission } \\
\text { (b/min) }\end{array}$} & Range & $95.0-123.0$ & $57.0-119.0$ & \multirow{2}{*}{$\mathrm{t}=3.992$} & \multirow{2}{*}{$<0.001 *$} \\
\hline & Mean \pm SD & $108.3 \pm 12.1$ & $90.1 \pm 17.2$ & & \\
\hline \multirow{2}{*}{$\begin{array}{l}\text { RR on admission } \\
\text { (cycle/min) }\end{array}$} & Range & $22.0-26.0$ & $20.0-37.0$ & \multirow{2}{*}{$\mathrm{t}=3.042$} & \multirow{2}{*}{$0.004 *$} \\
\hline & Mean \pm SD & $23.5 \pm 1.9$ & $27.1 \pm 6.2$ & & \\
\hline \multirow{2}{*}{ Temperature $\left({ }^{0} \mathrm{C}\right)$} & Range & $37.0-37.3$ & $37.0-37.4$ & \multirow{2}{*}{$\mathrm{t}=0.444$} & \multirow{2}{*}{0.661} \\
\hline & Mean \pm SD & $37.2 \pm .1$ & $37.2 \pm .1$ & & \\
\hline \multirow{2}{*}{ Oxygen saturation (\%) } & Range & $88.0-98.0$ & $70.0-100.0$ & \multirow{2}{*}{$\mathrm{t}=5.510$} & \multirow{2}{*}{$<0.001 *$} \\
\hline & Mean $\pm \mathrm{SD}$ & $94.3 \pm 3.3$ & $85.1 \pm 7.9$ & & \\
\hline
\end{tabular}

GCS: Glasgow coma scale; $n$ : number; IQR: interquartile range; SD: standard deviation; $Z_{M W}:$ Mann-

Whitney test; $t$ : Independent samples T-test; * significant at $p$ <0.05; SBP: Systolic Blood pressure; DBP:

Diastolic Blood pressure; HR: Heart rate; RR: Respiratory rate 
Table (4): Statistical comparison (Independent samples T-test) between the studied groups regarding the most common routine laboratory investigations

\begin{tabular}{|c|c|c|c|c|c|}
\hline & \multicolumn{2}{|c|}{ Groups } & \multicolumn{2}{|c|}{ Tests of significance } \\
\hline & & $\begin{array}{l}\text { Survivors } \\
(\mathrm{n}=12)\end{array}$ & $\begin{array}{l}\text { Non-survivors } \\
\quad(\mathbf{n}=\mathbf{3 4})\end{array}$ & $\begin{array}{c}\text { Test } \\
\text { statistic }\end{array}$ & $\mathbf{P}$ \\
\hline \multirow[t]{2}{*}{ Hb $(\mathrm{gm} / \mathrm{dL})$} & Range & $10.9-14.0$ & $10.8-12.7$ & \multirow{2}{*}{$\mathrm{t}=2.390$} & \multirow{2}{*}{$0.024 *$} \\
\hline & Mean \pm SD & $12.6 \pm 1.2$ & $11.9 \pm 0.8$ & & \\
\hline \multirow{2}{*}{ SGPT (up to 35 U/L) } & Range & $14.0-43.0$ & $13.0-43.0$ & \multirow{2}{*}{$\mathrm{t}=0.520$} & \multirow{2}{*}{0.610} \\
\hline & Mean \pm SD & $26.0 \pm 11.6$ & $24.1 \pm 8.8$ & & \\
\hline \multirow{2}{*}{ SGOT (up to $41 \mathrm{U} / \mathrm{L}$ ) } & Range & $11.0-32.0$ & $11.0-40.0$ & \multirow{2}{*}{$t=0.722$} & \multirow{2}{*}{0.478} \\
\hline & Mean \pm SD & $22.6 \pm 7.2$ & $24.4 \pm 7.6$ & & \\
\hline \multirow{2}{*}{ PT (12-14 seconds) } & Range & $12.8-14.7$ & $12.7-15.6$ & \multirow{2}{*}{$\mathrm{t}=1.971$} & \multirow{2}{*}{0.055} \\
\hline & Mean \pm SD & $13.3 \pm 0.7$ & $13.9 \pm 1.0$ & & \\
\hline \multirow{2}{*}{ PTT (25-40 seconds) } & Range & $35.0-39.0$ & $32.0-40.0$ & \multirow{2}{*}{$\mathrm{t}=0.890$} & \multirow{2}{*}{0.380} \\
\hline & Mean \pm SD & $36.7 \pm 1.7$ & $36.1 \pm 2.5$ & & \\
\hline \multirow{2}{*}{ INR (1-1.3) } & Range & $1.0-1.2$ & $1.0-1.6$ & \multirow{2}{*}{$t=3.165$} & \multirow{2}{*}{$0.003^{*}$} \\
\hline & Mean \pm SD & $1.1 \pm 0.1$ & $1.2 \pm 0.2$ & & \\
\hline \multirow{2}{*}{ Creatinine $(0.2-1.2 \mathrm{mg} / \mathrm{dL})$} & Range & $0.8-1.2$ & $0.8-1.3$ & \multirow{2}{*}{$\mathrm{t}=1.136$} & \multirow{2}{*}{0.270} \\
\hline & Mean \pm SD & $1.0 \pm 0.2$ & $1.1 \pm 0.2$ & & \\
\hline \multirow{2}{*}{ Urea $(15-45 \mathrm{mg} / \mathrm{dL})$} & Range & $22.0-29.0$ & $21.0-38.0$ & \multirow{2}{*}{$\mathrm{t}=1.931$} & \multirow{2}{*}{0.060} \\
\hline & Mean \pm SD & $25.0 \pm 2.7$ & $28.4 \pm 5.9$ & & \\
\hline \multirow{2}{*}{$\mathrm{Na}(135-145 \mathrm{mEq} / \mathrm{L})$} & Range & $139.4-150.0$ & $137.0-159.0$ & \multirow{2}{*}{$t=1.652$} & \multirow{2}{*}{0.106} \\
\hline & Mean \pm SD & $142.9 \pm 4.1$ & $146.5 \pm 7.0$ & & \\
\hline \multirow{2}{*}{$\mathrm{K}(3.5-5.5 \mathrm{mEq} / \mathrm{L})$} & Range & $3.2-4.2$ & $2.8-3.4$ & \multirow{2}{*}{$\mathrm{t}=3.802$} & \multirow{2}{*}{$0.002 *$} \\
\hline & Mean \pm SD & $3.6 \pm 0.4$ & $3.1 \pm 0.2$ & & \\
\hline \multirow{2}{*}{$\begin{array}{l}\text { Magnesium (1.7-2.5 } \\
\mathrm{mEq} / \mathrm{L})\end{array}$} & Range & $1.4-2.2$ & $0.7-1.6$ & \multirow{2}{*}{$\mathrm{t}=3.191$} & $0004 *$ \\
\hline & Mean \pm SD & $1.9 \pm 0.4$ & $1.1 \pm 0.4$ & & 0.004 \\
\hline
\end{tabular}

Hb: hemoglobin; SGPT: serum glutamic pyruvic transaminase; SGOT: serum glutamic oxaloacetic transaminase; PT: prothrombin time; PTT: partial thromboplastin time; INR: international normalized ratio; Na: sodium; K: potassium; $n:$ number; SD: standard deviation; $t$ : Independent samples T-test; * significant at $p<0.05$. 
Table (5): Statistical study of arterial blood gas parameters and duration of hospital stay in the survivor and non-survivor groups

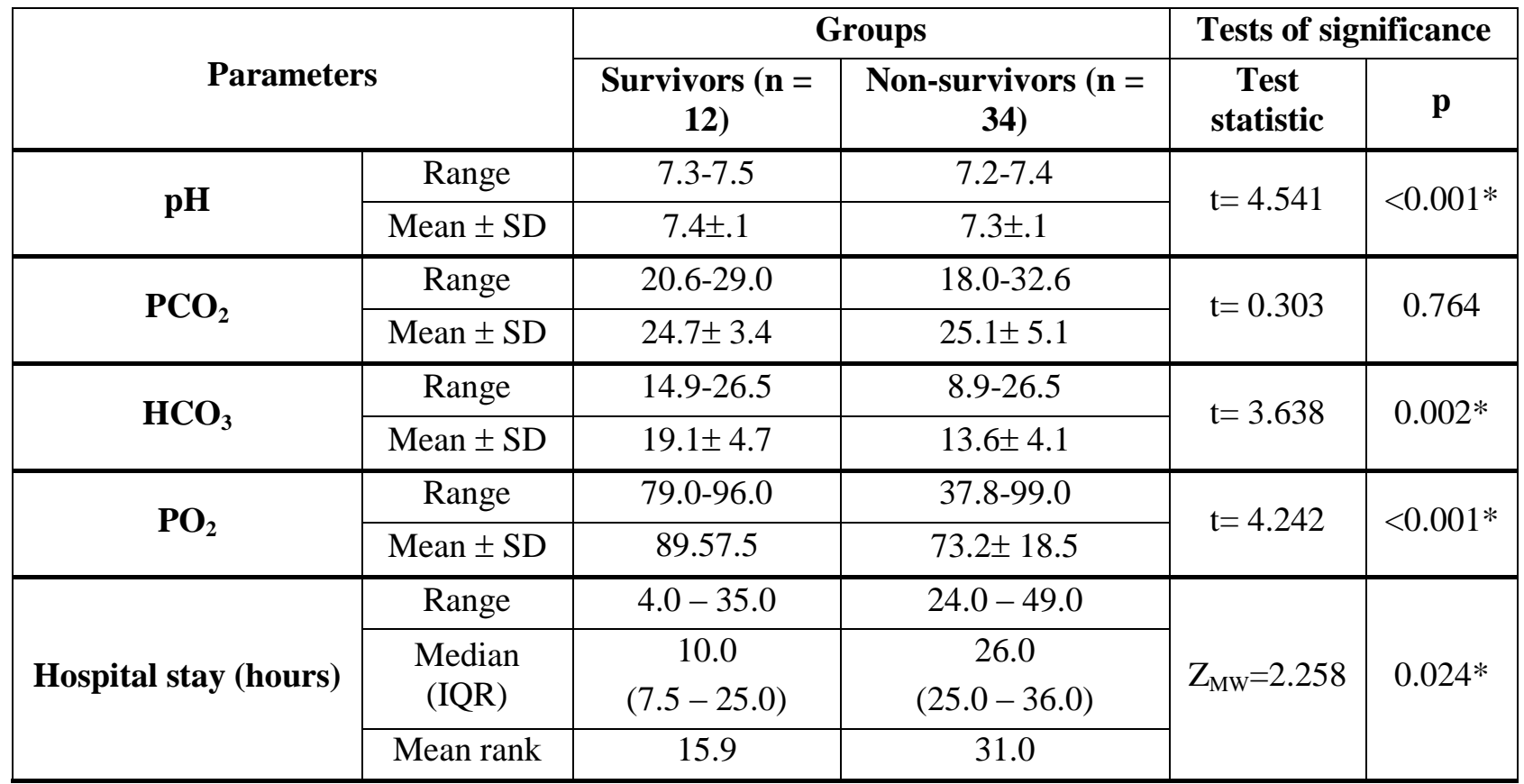

n: number; IQR: interquartile range; $S D$ : standard deviation; $Z_{M W}:$ Mann-Whitney test; $t$ : Independent samples T-test; * significant at $p<0.05$

Table (6): Statistical analysis of blood lactate, pyruvate and lactate/pyruvate (L/P) ratio in the survivor and non-survivor groups

\begin{tabular}{|c|c|c|c|c|c|}
\hline & \multirow{2}{*}{\multicolumn{2}{|c|}{ Groups }} & \multicolumn{2}{|c|}{ Tests of significance } \\
\hline & & & & \multirow{2}{*}{ Test statistic } & \multirow{2}{*}{$\mathbf{p}$} \\
\hline & & Survivors $(\mathrm{n}=12)$ & Non-survivors $(n=34)$ & & \\
\hline \multirow{3}{*}{$\begin{array}{c}\text { Lactate } \\
(4.5-20 \mathrm{mg} / \mathrm{dL})\end{array}$} & Range & $16.8-85.0$ & $50.0-91.0$ & \multirow{3}{*}{$\mathrm{Z}_{\mathrm{MW}}=3.309$} & \multirow{3}{*}{$0.001 *$} \\
\hline & Median (IQR) & $28.0(19.2-77.0)$ & $82.0(70.0-87.0)$ & & \\
\hline & Mean rank & 12.5 & 27.4 & & \\
\hline \multirow{2}{*}{$\begin{array}{c}\text { Pyruvate } \\
(0.3-0.7 \mathrm{mg} / \mathrm{dL})\end{array}$} & Range & $0.3-1.6$ & $0.7-1.0$ & \multirow{2}{*}{$\mathrm{t}=0.700$} & \multirow{2}{*}{0.498} \\
\hline & Mean \pm SD & $1.0 \pm .4$ & $0.9 \pm .1$ & & \\
\hline \multirow{3}{*}{$\mathrm{L} / \mathrm{P}$ ratio } & Range & $12.0-97.5$ & $65.8-129.0$ & \multirow{3}{*}{$\mathrm{Z}_{\mathrm{MW}}=3.208$} & \multirow{3}{*}{$0.001 *$} \\
\hline & Median (IQR) & $43.2(22.1-87.6)$ & $92.4(71.4-97.8)$ & & \\
\hline & Mean rank & 12.8 & 27.3 & & \\
\hline
\end{tabular}

n: number; IQR: interquartile range; SD: standard deviation; $Z_{M W}:$ Mann-Whitney test; $t$ : Independent samples T-test; * significant at $p<0.05$ 
Table (7): Statistical correlation between blood lactate, pyruvate and lactate/pyruvate ratio with ingested amount of AlP, hospital delay, $\mathrm{pH}$ and blood $\mathrm{HCO}_{3}{ }^{-}$

\begin{tabular}{|c|c|c|c|c|}
\hline & & Lactate & Pyruvate & $\mathbf{L} / \mathbf{P}$ \\
\hline \multirow{2}{*}{ Ingested amount of ALP } & $\mathrm{r}_{\mathrm{s}}$ & 0.438 & 0.024 & 0.323 \\
\hline & $\mathrm{P}$ & $0.001 *$ & 0.866 & $0.022 *$ \\
\hline \multirow{2}{*}{$\begin{array}{l}\text { Duration between exposure } \\
\text { and arrival to hospital (time } \\
\text { delay in hours) }\end{array}$} & $\mathrm{r}_{\mathrm{s}}$ & 0.464 & 0.030 & 0.084 \\
\hline & $\mathrm{P}$ & $0.002 *$ & 0.836 & $0.001^{*}$ \\
\hline \multirow{2}{*}{ pH } & $\mathrm{r}_{\mathrm{s}}$ & -0.531 & 0.138 & -0.581 \\
\hline & $\mathrm{P}$ & $<0.001 *$ & 0.339 & $<0.001^{*}$ \\
\hline \multirow{2}{*}{$\mathrm{HCO}_{3}$} & $\mathrm{r}_{\mathrm{s}}$ & -0.347 & 0.165 & -0.394 \\
\hline & $\mathrm{P}$ & $0.014^{*}$ & 0.251 & $0.005^{*}$ \\
\hline
\end{tabular}

$\mathrm{r}_{\mathrm{s}}$ Spearman's rank-order correlation; * significant at $p<0.05 ;$ ALP: Aluminum Phosphide; Hco ${ }_{3}$ : Bicarbonates

Table (8): Comparison of AUC-ROC between blood lactate level and lactate/pyruvate ratio with $\mathrm{pH}$ of the blood, blood pressure, pulse and respiratory rate for prediction of mortality in the studied aluminum phosphide-poisoned patients

\begin{tabular}{|l|c|c|c|c|c|}
\hline Variables & AUC & $\mathbf{9 5 \%}$ CI & Cut-off value & Sensitivity (\%) & Specificity (\%) \\
\hline DBP on admission & 0.882 & 0.753 to 0.958 & $\leq 65$ & 73.5 & 100.0 \\
\hline SBP on admission & 0.868 & 0.735 to 0.949 & $\leq 100$ & 79.4 & 83.3 \\
\hline HR & 0.816 & 0.674 to 0.915 & $\leq 90$ & 64.7 & 100.0 \\
\hline RR & 0.637 & 0.482 to 0.774 & $>26$ & 52.9 & 100.0 \\
\hline pH & 0.892 & 0.765 to 0.964 & $\leq 7.33$ & 79.4 & 83.3 \\
\hline Lactate & 0.824 & 0.683 to 0.920 & $>28$ & 100.0 & 66.7 \\
\hline L/P ratio & 0.814 & $0.672-0.913$ & $>54.2$ & 100.0 & 66.7 \\
\hline Pyruvate & 0.505 & $0.354-0.656$ & $<0.99$ & 100.0 & 25.0 \\
\hline
\end{tabular}

AUC: area under the curve; ROC: Receiver operating characteristic; CI: confidence interval; *p is significant at <0.05; SBP: Systolic Blood pressure; DBP: Diastolic Blood pressure; HR: Heart rate; RR: Respiratory rate. 
Figures (1-3) of ROC curves revealed that blood lactate and L/P ratio were significant predictors of outcome in AlP poisoned patients $(\mathrm{P}<0.001)$ as the areas under the curves were 0.824 and 0.814 at cut off values was $>28$ and $>$ 54.2 , respectively (100\% sensitivity, $66.7 \%$ specificity). Regarding the ROC curve of pyruvate, it showed that the area under the curve 0.505 with sensitivity $100 \%$ and specificity $25 \%$ at cut off value $\leq 6.49$ ( $\mathrm{p}=$ 0.966).

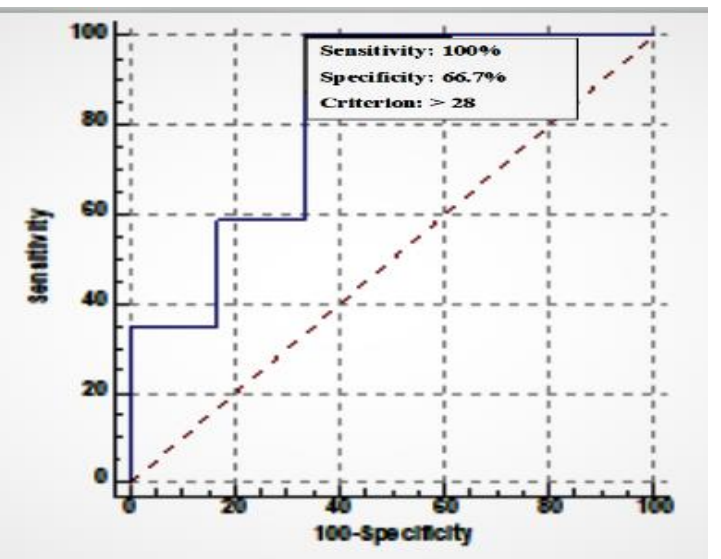

Figure (1): Receiver operating characteristic (ROC) curve of blood lactate level for prediction of the outcome in aluminum phosphide-poisoned patients (area under the curve $=0.824 \& 95 \%$ confidence interval $=0.683-0.920)$ with $\mathrm{P}<0.001 *$

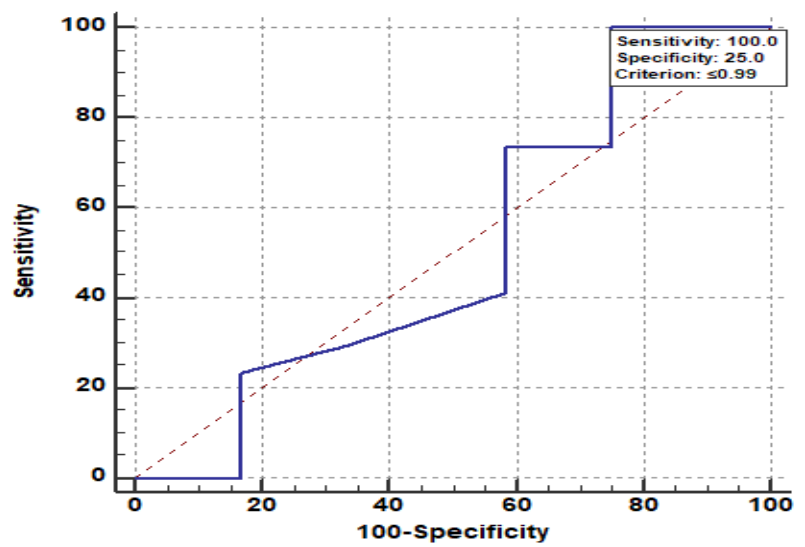

Figure (2): Receiver operating characteristic (ROC) curve of blood pyruvate level for prediction of the outcome in aluminum phosphide-poisoned patients (area under the curve $=$ $0.505 \& 95 \%$ confidence interval $=0.354-0.656$ ) with $\mathrm{P}=0.966$

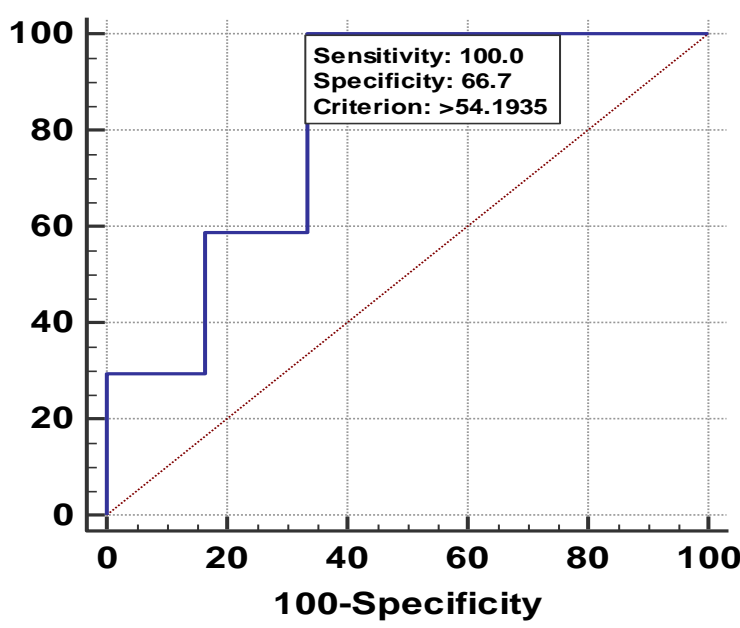

Figure (3): $\quad$ Receiver operating characteristic (ROC) curve of blood lactate/pyruvate ratio for prediction of the outcome in aluminum phosphide-poisoned patients (area under the curve $=$ $0.814 \& 95 \%$ confidence interval $=0.672-0.913$ ) with $\mathrm{P}<0.001^{*}$

The area under the ROC curve (AUC-ROC) of the studied vital signs and lactate were compared in Table (8). All the studied parameters had an AUC above 0.8 - which indicates their being excellent predictors for mortality - except for respiratory rate (AUCROC $=0.637)$ and blood pyruvate $(\mathrm{AUC}-\mathrm{ROC}=$ 0.505 ) which was a poor predictor of mortality. The blood $\mathrm{pH}$ had the highest discriminatory power as regards mortality (AUC-ROC = 0.892), followed by DBP on admission (AUCROC $=0.882$ ), then SBP on admission (AUCROC $=0.868)$, lactate $($ AUC-ROC $=0.824)$, $\mathrm{L} / \mathrm{P}$ ratio $(\mathrm{AUC}-\mathrm{ROC}=0.814$ ) and respiratory rate $(\mathrm{AUC}-\mathrm{ROC}=0.637)$. The blood $\mathrm{pH}-$ at a cut-off value $\leq 7.33$ - had a sensitivity of $79.4 \%$ (it identified $79.4 \%$ dead cases in the studied sample) and a specificity of $83.3 \%$ (it identified $83.3 \%$ of survivors). For the DBP on admission, the sensitivity and specificity were $73.5 \%$ and $100 \%$, respectively, at a cut-off value $\leq 65$ mmHg. The SBP on admission had $79.4 \%$ sensitivity and $83.3 \%$ specificity at cut-off value $\leq 100 \mathrm{mmHg}$. The blood lactate and $\mathrm{L} / \mathrm{P}$ ratio had $100 \%$ sensitivity and $66.7 \%$ specificity at a cut-off values $>28$ and $>54.2$, respectively. For heart rate, the sensitivity and specificity were $64.7 \%$ and $100 \%$ at a cut-off value $\leq 90 \mathrm{~b} / \mathrm{min}$. 
Finally, the respiratory rate had a sensitivity of $52.9 \%$ and a specificity of $100 \%$ at a cut-off value $>26$ cycle/min.

\section{DISCUSSION}

AlP is highly toxic rodenticides with fatal harmful effects. The incidence of AlP poisoning in developing countries rises due to wide availability and its cheapness in price. Both ingestion and inhalation of AlP can cause multisystem manifestations in humans including gastrointestinal,

musculoskeletal, cardiovascular, respiratory, nervous, and urogenital system (Nosrati et al., 2013 and Alzahrani et al., 2017).

The current study revealed significant high mortality rate $73.9 \%$ that matched with Ahmadi et al. (2018) who said that mortality rate from phosphides is $70-100 \%$. In contrast, Louriz et al. (2009), Nejad et al. (2012), Sulaj et al. (2015) and El-Sarnagawy (2017) who reported that death rates of acute ALP poisoning were $44.7 \%, 49 \%, 41.8 \%$ and $44.1 \%$, respectively. This could be explained unrestrained marketing, low cost of ALP, absence of awareness about AlP health dangers and lack of specific antidote (Sulaj et al., 2015; Hashemi-Domeneh et al., 2016).

In this study, the suicidal manner of AlP was the major one $(88.2 \%)$. Also, there was significant difference between survival and nonsurvival regarding amount ingested and time delay. These results were coincided with Hegazy et al. (2019) and Sheta et al. (2019) who indicated that suicidal attempts accounted $92.2 \%$ and $86.7 \%$ of poisoned cases, respectively. Higher susceptibility to excitability, depression, and stresses of failure in education, love, or work or lack of employment opportunities are triggering factors of theses suicide trials. Sheta et al. (2019) reported the time passed since exposure to AlP ranged from 0.5 to 6 hours resembling the current study results, which could be explained by the intention of some subjects in attempting suicide just to draw attention and to gain help and sympathy from their families, so they rapidly seek for medical treatment.

In the present study, regarding duration of hospital stay as an indicator of outcome in AlP poisoning, there was a statistically significant longer duration of hospital stay in non-survived than survived, because most of the survived patients presented with moderate clinical manifestations with ingestion of smaller amount of AlP. Elgazzar et al., (2019) demonstrated similar results. However, Severe poisoning can lead to death in about 3 hours, ranging between 1-48 hours (Alnasser et al., 2018). On the contrary, Hegazy et al. (2019) stated that survivors stayed in hospital longer than nonsurvivors as the majority of non-survivors reached emergency room with severe cardiogenic shock that produced death in less than 48 hours.

The current study showed significantly reduced systolic and diastolic blood pressure in non-survived group. Those findings were agreed with El-Sarnagawy (2017) who contributed hypotension to great intravascular volume depletion from vascular wall insufficiency, which leads to hypovolemic shock. Circulatory failure in acute aluminum phosphide poisoning is due direct effects on cardiac myocytes consequently the fatal diminishing myocardial contractility resulted, fluid loss and adrenal gland damage (Taghaddosinejad et al., 2016).

In the present study, statistically significant decrease of hemoglobin level, potassium and magnesium levels were recorded in nonsurvived group. Increased production of Heinz bodies (i.e. denatured hemoglobin) and hemichrome are detected following $\mathrm{PH}_{3}$ reaction that may explain the reduction in heme capacity (Karimani et al., 2018). Hypokalemia might be contributed to vomiting which presented in most of non-survivors (Hegazy et al., 2019).

In this study, INR presented significant difference between both groups. There was 
partial agreement with El Nagar and El Mahdy (2011) who revealed that $33 \%$ of poisoned patients had prolonged PT, 10\% had low prothrombin concentration while INR and platelet count were within normal range on admission. Moreover, Louriz et al. (2009) stated a significant low prothrombin time in the non-survived victims. These findings were attributed to the toxic effects on the liver with impairment of coagulation factors synthesis.

Mathai and Bhanu (2010) and Taghaddosinejad et al. (2016) discussed that there is a big association between hypomagnesaemia in AlP and abnormal electrocardiographic findings with reduction in mortality rates with magnesium therapy; also, they reported hypokalemia in $48 \%$ of patients.

Regarding arterial blood gases, metabolic acidosis was evident significantly in the nonsurvived group. This result was in agreement with Hosseinian et al. (2011) and ElSarnagawy (2017) who reported that $43.8 \%$ and $41.1 \%$ of their patients suffered from metabolic acidosis, respectively. Metabolic acidosis is considered one of the most common finding in AlP poisoning, which resulted from circulatory failure and tissue hypoperfusion as evidenced by diminished oxygen saturation with hypoxia (Hassanian-Moghaddam and Shahbazi, 2012). In accordance, Sheta et al. (2019) declared the same result when they detected $43.3 \%$ of their patients presents with hypoxia. Proudfoot (2009) explained hypoxia from phosphine gas, which bothers mitochondrial morphology, hinders about $70 \%$ of mitochondrial oxidative respiration, and leads to massive defect in mitochondrial membrane potential, hence suppression of cytochrome oxidase (Singh et al., 2006).

The current study showed a significantly higher blood lactate level and L/P ratio in nonsurvived group. This result was in agreement with Erfantalab et al. (2017) and Rimachi et al. (2012). Hyperlactatemia in AlP poisoning in the early hours after ingestion might be due to energy insufficiency as a result of inhibition of cytochrome-c that blocks of oxidative phosphorylation and poor tissue perfusion that leads to cellular hypoxia, and oxidative stress with increased activity of $\mathrm{Na}^{+} / \mathrm{K}^{+}$-ATPase through a possible interaction with mitochondrial electron transport chain which may lead to metabolic acidosis and increased lactate production (Agarwal et al., 2014).

Similarly, Debray et al. (2006) indicated that patients with circulatory shock and increased lactate levels often have an elevated $\mathrm{L} / \mathrm{P}$ ratio and that raised $\mathrm{L} / \mathrm{P}$ ratios were associated with a poor outcome, which backed increased lactate to decreased lactate clearance and muscle hyperactivity due to seizures.

In the current study, there was positive significant correlation between blood lactate level and both amount ingested and time delay. While a negative correlation was detected between blood lactate level \& L/P ratio and both $\mathrm{pH}$ and $\mathrm{HCO}_{3}$. These results were comparable to Erfantalab et al. (2017) findings. These results ensued that if cellular respiration is diminished; pyruvate oxidation will reduce, resulting in lactic acidosis. In such states, reduced forms of oxido-reduction coenzymes predominate and $\mathrm{L} / \mathrm{P}$ ratio is increased.

\section{CONCLUSION \& RECOMMENDATION}

Unfortunately, there is no definitive management or specific antidote for this rapidly progressing poisoning, and treatment remains mainly supportive. Immediate diagnosis and continued intensive supportive measures are critical in the management of AlP poisoning.

Preventive strategies therefore need to be adopted at a national level to spread awareness among the population. Health promotion policies should focus on both general public and AlP users if the total ban is not possible. First responders should receive training to recognize clinical signs and 
symptoms of airborne AlP poisoning and respond quickly and appropriately.

Considering the highly fatal nature of this agent, regulatory strategies and action plans for controlled AlP distribution should be enforced all over the world. Shop keepers and vendors have to not sell the tablets to young people and children without proper verification and authorization.

\section{REFERENCES}

Agarwal, A.; Robo, R.; Jain, N.; Gutch, M.; Consil, S. and Kumar, S. (2014): Oxidative stress determined through the levels of antioxidant enzymes and the effect of $\mathrm{N}$-acetyl cycteine in aluminum phosphide poisoning. Indian Journal of Critical Care Medicine, 18(10): 666-671.

\section{Ahmadi, J.; Joukar, S.; Anani, H. and} Karami-Mohajeri, S. (2018): Dihydroxyacetone as a definitive treatment for aluminium phosphide poisoning in rats. Archives of Industrial Hygiene and Toxicology. The Journal of Institute for Medical Research and Occupational Health, 69(2): 169-177.

Alnasser, S.; Hussain, S.M.; Kirdi, T.S. and Ahmed, A. (2018): Aluminum phosphide poisoning in Saudi Arabia over a nine-year period. Annals of Saudi medicine, 38(4): 277-283.

Alzahrani, S.H.; Ibrahim, N.K.; Elnour, M.A. and Alqahtani, A.H. (2017): Fiveyear epidemiological trends for chemical poisoning in Jeddah, Saudi Arabia. Annals of Saudi medicine, 37(4): 282-289.

Andersen, L. W.; Mackenhauer, J.; Roberts, J. C.; Berg, K. M.; Cocchi, M. N. and Donnino, M. W. (2013): Etiology and therapeutic approach to elevated lactate. Mayo Clinic Proceedings, 88(10): 1127-1140.
Broder, G. and Weil, M.H. (1964): Excess Lactate: An Index of Reversibility of Shock in Human Patients. Science, 27(143): 1457-1459.

Bumbrah, G.S.; Krishan, K.; Kanchan, T.; Sharma, M. and Sodhi, G.S. (2012): Phosphide poisoning: a review of literature. Forensic science international, 214(1-3): 16.

Cervellin, G.; Comelli, I.; Rastelli, G.; Picanza, A. and Lippi, G. (2014): Initial blood lactate correlates with carboxyhemoglobin and clinical severity in carbon monoxide poisoned patients. Clin Biochem, 47: 298-301.

Chaudhary, S; Momin, S.G.; Vora, D.H.; Modi, P.; Chauhan, V. and Chotaliya, D. (2013): An epidemiological study of fatal aluminium phosphide poisoning at Rajkot. IOSR Journal of pharmacy, 3(1): 17-23.

Debray, F.G.; Mitchell, G.A.; Allard, P.; Robinson, B.H.; Hanley, J.A. and Lambert, M. (2006): Diagnostic Accuracy of Blood Lactate-to-Pyruvate Molar Ratio in the Differential Diagnosis of Congenital Lactic Acidosis. Clinical Chemistry, 53(5): 916-921.

DeLong, E.R.; DeLong, D.M. and ClarkePearson, D.L. (1988): "Comparing the areas under two or more correlated receiver operating characteristic curves: a nonparametric approach". Biometrics, 44 (3): 837-845.

El Nagar, A.M. and El Mahdy, N.M. (2011): Zinc phosphide toxicity with a trial of tranexamic acid in its management. J Advan Res, 2: 49-56.

Elgazzar, F.M.; Keshk, W. and Khalifa, H. (2019): Early L-carnitine Therapy in Severe Acute Aluminum Phosphide Poisoning: A Randomized Controlled Clinical Trial. The Egyptian Journal of 
Forensic Sciences and Applied Toxicology, 19(4):147-164.

El-Sarnagawy, G.N. (2017): Predictive factors of mortality in acute aluminum phosphide poisoning: 5 years retrospective study in Tanta Poison Control Unit. Ain Shams J Forensic Med Clin Toxicol, 29: 70-79.

Erfantalab, P.; Soltaninejad, K.; Shadnia, S.; Zamani, N.; Hassanian-Moghaddam, H.; Mahdavinejad, A. and Damaneh, B.H. (2017): Trend of blood lactate level in acute aluminum phosphide poisoning. World J Emerg Med, 8(2): 116-120.

Gurjar, M.; Baronia, A.K.; Azim, A. and Sharma, K. (2011): Managing aluminum phosphide poisonings. Journal of Emergencies, Trauma and Shock, 4(3): 378.

Hashemi-Domeneh, B., Zamani, N., Hassanian-Moghaddam, H., Rahimi, M., Shadnia, S., Erfantalab, P. and Ostadi, A. (2016): A review of aluminium phosphide poisoning and a flowchart to treat it. Archives of Industrial Hygiene and Toxicology, 67(3): 183-193

Hassanian-Moghaddam, H. and Shahbazi, A. (2012): Gastric decontamination: A new approach to metal phosphide fumigant ingestion. Clinical Toxicology, 50(5): 435437.

Hegazy, M.M.; Elagamy, S.E. and Salem, E.A.A., (2019): Pattern and predictors of death from aluminum and zinc phosphide poisoning: A two years prospective study. The Egyptian Journal of Forensic Sciences and Applied Toxicology, 19(2):73-86.

Hinkle, D.E.; Wiersma, W. and Jurs, S.G. (2003): Applied Statistics for the Behavioral Sciences. 5th ed. Boston: Houghton Mifflin.

Hosseinian, A.; Pakravan, N.; Rafiei, A. and Feyzbakhsh, S.M. (2011): Aluminum phosphide poisoning known as rice tablet: a common toxicity in North Iran. Indian Journal of Medical Sciences, 65(4): 143150.

Karimani, A.; Mohammadpour, A.H.; Zirak, M.R.; Rezaee, R.; Megarbane, B.; Tsatsakis, A. and Karimi, G. (2018): Antidotes for aluminum phosphide poisoning - An update. Toxicol Rep, 5: 1053-1059.

Kucherenko, I.S.; Topolnikova, Y.V. and Soldatkin, O.O. (2018): Advances in the biosensors for lactate and pyruvate detection for medical applications: a review, Trends in Analytical Chemistry, 110: 160-172.

Louriz, M., Dendane, T., Abidi, K., Madani, N., Abouqal, R. and Zeggwagh, A.A. (2009): Prognostic factors of acute aluminum phosphide poisoning. Indian journal of medical sciences, 63(6): 227234.

Mathai, A. and Bhanu, M.S. (2010): Acute aluminum phosphide poisoning: Can we predict mortality? Indian J Anaesth, 54(4): 302-307.

Mégarbane, B., Deye, N., Malissin, I. and Baud, F.J. (2010): Usefulness of the serum lactate concentration for predicting mortality in acute beta-blocker poisoning, Clinical

Toxicology, 48(10): 974-978.

Mehrpour, O.; Aghabiklooei, A.; Abdollahi, M. and Singh, S. (2012): Severe Hypoglycemia Following Acute Aluminum Phosphide (Rice Tablet) Poisoning; A Case Report and Review of the Literature. Acta Medica Iranica, 50(8): 568-571.

Mizock, B.A. and Falk, J.L. (1992): Lactic acidosis in critical illness. Crit Care Med, 20: 80-93.

Moghadamnia, A. A. (2012): An update on toxicology of aluminum phosphide. DARU 
Journal of Pharmaceutical Sciences, 20(1): 25.

Nosrati, A.; Karami, M. and Esmaeilnia, M. (2013): Aluminum phosphide poisoning: A case series in north Iran. Asia Pacific Journal of Medical Toxicology, 2(3): 111113.

Proudfoot, A.T. (2009): Aluminum and zinc phosphide poisoning. Clinical Toxicology Journal, 47(2): 89-100

Pundir, C.S.; Narwal, V. and Batra, B. (2016): Determination of lactic acid with special emphasis on biosensing methods: A review, Biosens. Bioelectron, 86: 777-790.

Rimachi, R., De Carvahlo, F.B., OrellanoJimenez, C., Cotton, F., Vincent, J.L. and De Backer, D. (2012): Lactate/pyruvate ratio as a marker of tissue hypoxia in circulatory and septic shock. Anaesthesia and intensive care, 40(3): 427-432.

Sagah, G. A.; Oreby, M. M.; El-Gharbawy, R. M., and Fathy, A. S. (2015): Evaluation of Potential Oxidative Stress in Egyptian Patients with Acute Zinc Phosphide Poisoning and the Role of Vitamin C. International Journal of Health Sciences, 9(4): 375-385.

Shah, A. D.; Wood, D. M. and Dargan, P. I. (2011): Understanding lactic acidosis in paracetamol (acetaminophen) poisoning. British Journal of Clinical Pharmacology, 71(1): 2028.

Sheta, A.A.; El-Banna, A.S.; Elmeguid, R.A.; Mohamed, H.E.; Gad, N.H. (2019): A study of the predictive factors of mortality in acute poisoning with aluminum phosphide with special reference to echocardiography and SOFA score. Environ Sci Pollut Res Int, 26(32): 33135-33145.

Singh, S.; Bhalla, A.; Verma, S.K.; Kaur. A. and Gill, K. (2006): Cytochrome-c oxidase inhibition in 26 aluminum phosphide poisoned patients. Clin Toxicol (Phila), 44:155-158.
Sulaj, Z., Drishti, A., Çeko, I., Gashi, A. and Vyshka, G. (2015): Fatal aluminum phosphide poisonings in Tirana (Albania), 2009-2013. DARU Journal of Pharmaceutical Sciences, 23(1): 8.

Sweilum, O.A.H.; Kandeel, F.S. and Noya, D.A.R., (2017): Management of acute aluminum phosphide toxicity in rat model with a novel intervention, a trial of boric acid. The Egyptian Journal of Forensic Sciences and Applied Toxicology, 17(2): 57-72.

Taghaddosi Nejad, F., Banagozar Mohammadi, A., Behnoush, B., Kazemifar, A., Zaare Nahandi, M., Dabiran, S. and Jamalian, M. (2012): Predictors of poor prognosis in aluminum phosphide intoxication. Iranian Journal of Toxicology, 6(16): 610-614.

Taghaddosinejad, F., Farzaneh, E., Ghazanfari-Nasrabad, M., Eizadi-Mood, N., Hajihosseini, M. and Mehrpour, $O$. (2016): The effect of $\mathrm{N}$-acetyl cysteine (NAC) on aluminum phosphide poisoning inducing cardiovascular toxicity: a casecontrol study. Springerplus, 5(1): 1948.

Yeh, H.C.; Ting, I.W.; Tsai, C.W.; Wu, J.Y. and Kuo, C.C. (2017): Serum lactate level and mortality in metformin-associated lactic acidosis requiring renal replacement therapy: a systematic review of case reports and case series. BMC Nephrology, 18: 229. 


\section{الملخص العربي}

\section{اللاكتات والبيروفات بالدم ونسبة اللاكتات للبيروفات كمؤشرات حيوية للتنبؤ بمخرجات التسمم الحاد بفوسفيد الألمونيوم}

a علياء عبد الحكم هديبa ، نعيمه محمود الحصري

a قسم الطب الشـرعي والسموم الإكلينيكية، كلية الطب، جامعة طنطا، طنطا، مصر

يعد فوسفيد الألو منيوم مبيد آفات سام ير افقه معدل وفيات مرتفع بعد التعرض الحاد بطرق مختلفة. الهدف من هذه الدراسة هو تقييم دور مستوى اللاكتات و البيروفات بالدم ونسبة اللاكتات للبيروفات كمتنبئات للتسمم الحاد بفوسفيد الألومنيوم. طرق البحث: تم تضمين جميع المرضى الذين يعانون من التسمم الحاد بفوسفيد الألومنيوم وتم تتويمهم بوحدة مكافحة السموم مستشفى الطوارئ -جامعة طنطا، طنطا، مصر، في الفترة من أكتوبر 9 ــ إلى نهاية نوفمبر 9 اـr. خضع جميع المرضى (7؟ مريضًا) لأخذ تاريخ شامل للتسمم وللفحص البدني و التحاليل المخبرية الروتينية، وتم استخدام ثلاثة ملليلتر من الدم لتحديد مستوي اللاكتات و البيروفات به.

النتائج: الطريقة الغالبة للتسمم في هذه الدراسة هي الانتحار بسبب تناول أقراص فوسفيد الألومنيوم. وكان معدل الوفيات 9. 9 \% . سجل ضغط الدم الانقباضي و الانبساطي اختلافًا إحصائيًا كبيرًا بين المجمو عتبن محل الدر اسة. كما سجل إثباع الأكسجين، درجة حموضة الدم، البيكربونات، النسبة المئوية للأكسجين، منوسط نسبة الهيموجلوبين في الدم، البوتاسيوم و الماغنيسيوم انخفاضًا ذا قيمة إحصائية في حالات الوفيات مقارنة بمجموعة الناجين، كما أظهر مستوى اللاكتات بالدم ونسبة اللاكتات إلى البيروفات ارتفاعًا كبيرًا ذا قيمة إحصائية في المرضى غير الناجين، في حين أن مستوى البيروفات بالدم لم يظهر أي فرق ذي قيمة إحصائية بين المجمو عنين. كما تبين أن درجة حموضة الدم لها أعلى قوة تمييزية فيما يتعلق بالتتبؤ بالوفاة، تليها ضغط الدم الانبساطي، ثم ضغط الدم الانقباضي عند التنويم، مستوي اللاكتات، نسبة اللاكتات إلى البيروفات، وأخيرًا معدل التنفس والبيروفات. وكان تركيز اللاكتات في الدم ونسبة اللاكتات إلى البيروفات كمتنبئ

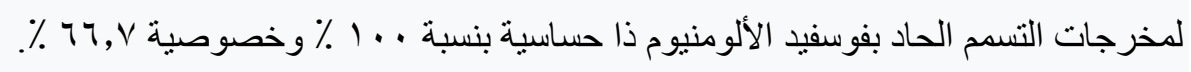
الخلاصة: تحديد مستوى اللاكتات بالدم له دور كمؤشر حيوي لتوقع نتيجة التسمم الحاد بفوسفيد الألومنيوم. 